\title{
Cholecystektomia laparoskopowa w trakcie leczenia riwaroksabanem
}

\section{Laparoscopic cholecystectomy during treatment with rivaroxaban}

\author{
Anna Szpotowicz ${ }^{1}$, Iwona Gorczyca-Michta², Beata Wożakowska-Kapłon², Małgorzata Krzciuk ${ }^{1}$ \\ ${ }^{1}$ Oddział Kardiologii Zespołu Opieki Zdrowotnej w Ostrowcu Świętokrzyskim \\ ${ }^{2}$ I Klinika Kardiologii i Elektroterapii Świętokrzyskiego Centrum Kardiologii w Kielcach
}

\section{Streszczenie}

U chorych z migotaniem przedsionków leczonych nowymi doustnymi antykoagulantami może zaistnieć konieczność wykonania procedur chirurgicznych w trybie nagłym. Autorzy przedstawiają przypadek pacjenta leczonego przeciwkrzepliwie riwaroksabanem w dawce $20 \mathrm{mg}$, wymagającego pilnej interwencji chirurgicznej. U 69-letniego chorego wykonano cholecystektomię laparoskopową po upływie 24 godzin od podania ostatniej dawki riwaroksabanu, nie stwierdzając powikłań krwotocznych.

Słowa kluczowe: riwaroksaban, cholecystektomia, leczenie

Folia Cardiologica 2016; 11, 5: 470-472

\section{Wstęp}

Podczas leczenia przeciwkrzepliwego nowymi doustnymi antykoagulantami (NOAC, new oral anticoagulants) często dochodzi do konieczności wykonania pilnych zabiegów operacyjnych, wymagających szybkiego przygotowania pacjenta do interwencji. Cholecystektomia laparoskopowa jest zabiegiem z wyboru w ostrym zapaleniu pęcherzyka żółciowego. Leczenie NOAC zwiększa ryzyko wystąpienia powikłań krwotocznych w trakcie pilnych zabiegów z przerwaniem ciągłości tkanek. Odwrócenie działania antykoagulacyjnego riwaroksabanu jest dość trudne. Aby zapewnić jak największe bezpieczeństwo podczas zabiegu operacyjnego, należy przeprowadzić go w odpowiednim czasie, który upłynął od przyjęcia ostatniej dawki leku. Autorzy przestawili przypadek mężczyzny przyjętego do planowej kardiowersji elektrycznej, leczonego przeciwkrzepliwie riwaroksabanem od 3 tygodni, u którego po powrocie rytmu zatokowego wystąpiły objawy ostrego zapalenia pęcherzyka żółciowego.

\section{Opis przypadku}

Mężczyzna w wieku 69 lat z przetrwałym migotaniem przedsionków, leczony z powodu nadciśnienia tętniczego, choroby niedokrwiennej serca, w trakcie leczenia przeciwkrzepliwego riwaroksabanem został przyjęty na oddział w celu próby przywrócenia rytmu zatokowego. Według skal oceny ryzyka zakrzepowo-zatorowego i ryzyka krwawienia chory otrzymał w $\mathrm{CHA}_{2} \mathrm{DS}_{2} \mathrm{C}$-VASc 2 punkty oraz w skali HAS-BLED 2 punkty. Przy przyjęciu mężczyzna był w stanie ogólnym dobrym, bez dolegliwości bólowych. W EKG wykazano migotanie przedsionków z rytmem komór 100/min. Chory regularnie od 3 tygodni był leczony przeciwkrzepliwe riwaroksabanem w dawce $20 \mathrm{mg}$ raz na dobe. W trakcie hospitalizacji wykonano badanie echokardiograficzne, nie stwierdzając odcinkowych zaburzeń kurczliwości z zachowaną funkcją skurczową lewej komory, frakcja wyrzutowa (EF, ejection fraction) była równa 58\%. W całodobowym monitorowaniu EKG zarejestrowano migotanie przedsionków z rytmem komór 80-90/min. 
Wykonano kardiowersję elektryczną prądem o energii $120 \mathrm{~J}$, uzyskując powrót rytmu zatokowego, który utrzymywał się do dnia wypisu. W 2. dobie hospitalizacji pacjent zgłosił bóle brzucha. Stwierdzono cechy ostrego brzucha, w badaniu ultrasonograficznym jamy brzusznej uwidoczniono kamicę pęcherzyka żółciowego. Rozpoznano ostre zapalenie pęcherzyka żółciowego, zalecono nawodnienie, leki przeciwbólowe i rozkurczowe, tramadol i drotawerynę. Ze względu na brak poprawy po leczeniu zachowawczym ustalono termin zabiegu w kolejnym dniu. U pacjenta przed operacją oznaczono następujące parametry układu krzepnięcia: czas protrombinowy (PT, prothrombin time) 13,6 (9-13,5 s), międzynarodowy współczynnik znormalizowany (INR, international normalized ratio) 1,16, czas koalinowo-kefalinowy (APTT, activated partial thromboplastin time) 45,6 s (37 s). Przy prawidłowej wartości współczynnika przesączania kłębuszkowego (GFR, glomerular filtration rate) wynoszącej $60 \mathrm{ml} / \mathrm{min} / 1,73 \mathrm{~m}^{2}$ odstawiono riwaroksaban 24 godziny przed zabiegiem. W kolejnym dniu, po uprzednim nawodnieniu, wykonano cholecystostomię laparoskopową. Zabieg odbył się bez powikłań. Włączono leczenie riwaroksabanem po uzyskaniu hemostazy w ciągu 8 godzin od zabiegu. W profilaktyce nawrotu arytmii zastosowano amiodaron. W okresie pooperacyjnym nie stwierdzono powikłań krwotocznych. Chorego wypisano do domu w 7. dobie hospitalizacji w stanie ogólnym dobrym.

\section{Omówienie}

Przy wyborze metod operowania zarówno pęcherzyka żółciowego, jak i kamicy przewodów żółciowych preferowana jest metoda laparoskopowa, która została zastosowana u opisywanego pacjenta [1]. Ponieważ odwrócenie działania antykoagulacyjnego, szczególnie w przypadku riwaroksabanu (ze względu na brak dostępnego antidotum), jest trudne, podstawowe znaczenie ma oszacowanie czasu od ostatniej dawki leku, którą pacjent przyjął, zwłaszcza u chorych z upośledzoną czynnością nerek. U opisywanego chorego klirens kreatyniny był w zakresie normy. Zgodnie ze stanowiskiem ekspertów u u chorych z GRF powyżej $50 \mathrm{ml} / \mathrm{min} / 1,73 \mathrm{~m}^{2}$ leczonych riwaroksabanem należy go odstawić minimum dobę przed zabiegiem [2]. Rutynowo oznaczanych parametrów krzepnięcia nie należy wykorzystać do monitorowania przeciwkrzepliwego efektu riwaroksabanu. Orientacyjną ocenę działania riwaroksabanu podejmuje się, oznaczając czas protrombinowy, testem swoistym zaś jest zmodyfikowany pomiar aktywności anty-Xa, który w Polsce jest mało dostępny. Hamowanie aktywności czynnika Xa oraz wpływ riwaroksabanu na PT zależą od zastosowanej dawki. Lek prowadzi także do wydłużenia APTT. W trakcie stosowania riwaroksabanu PT wynosił u operowanego pacjenta mniej niż $13 \mathrm{~s}$ (13,6 s). Gdy ryzyko przebiegu operacji oceniane jest jako duże (jak w przypadku operacji kardio-, torako-, a także neurochirurgicznych, ortopedycznych, naczyniowych i w obrębie jamy brzusznej), należy odstawić riwaroksaban 48 godzin przed zabiegiem, zarówno wtedy, gdy czynność nerek jest w normie, jak i wówczas, gdy GFR znajduje się w zakresie 30-50 ml/min/1,73 $\mathrm{m}^{2}$. Gdy GFR wynosi mniej niż $30 \mathrm{ml} / \mathrm{min} / 1,73 \mathrm{~m}^{2}$, zalecane jest wydłużenie przerwy w leczeniu od przyjęcia ostatniej dawki leku do inwazyjnego zabiegu: do 2 dni u leczonych riwaroksabanem przy zabiegach o małym ryzyku krwawienia i do 4 dni przy zabiegach o dużym ryzyku krwawienia [3].

Zabiegi endoskopowe, a także laparoskopowe najczęściej wiążą się z małym ryzykiem krwawienia. Ryzyko krwawienia w takich sytuacjach zwiększa się w przypadku obecności dodatkowych czynników, takich jak choroby przewlekłe czy zaawansowany wiek. Chory nie miał dodatkowych obciążeń zwiększających ryzyko krwawienia. Podjęto również działania mające na celu zminimalizowanie ryzyka krwawienia okołooperacyjnego, takie jak wybór mało inwazyjnej metody operacyjnej, wyznaczenie doświadczonego operatora, wykonanie dokładnej hemostazy miejsca operacji (w loży po pęcherzyku żółciowym umieszczono opatrunek hemostatyczny z oksycelulozy), odpowiednie przygotowanie chorego przez między innymi nawodnienie. Po upływie 8 godzin od zakończenia zabiegu operacyjnego, gdy hemostaza miejscowa była zadowalająca, ponownie rozpoczęto leczenie riwaroksabanem [4]. Podjęto decyzję o włączeniu leczenia po uprzednim wykonaniu badania ultrasonograficznego jamy brzusznej w celu wykluczenia potencjalnego krwawienia.

\section{Podsumowanie}

Na podstawie przedstawionego przypadku można stwierdzić, że cholecystektomia laparoskopowa w trakcie leczenia riwaroksabanem jest zabiegiem małego ryzyka krwawienia. U każdego chorego jednak należy indywidualnie rozpatrywać czynniki zwiększające okołooperacyjne ryzyko krwawienia, a także zatorowania ze względu na odstawienie leczenia przeciwkrzepliwego.

\section{Konflikt interesów}

Autorki deklarują brak konfliktu interesów. 


\section{Abstract}

In patients treated with the new oral anticoagulants with atrial fibrillation may need to perform surgical procedures in emergency. The authors present a case of a patient treated with the anticoagulation with rivaroxaban 20 mg requiring urgent surgical intervention. At 69-year-old patient underwent laparoscopic cholecystectomy after 24 hours after the last dose of rivaroxaban, and found no bleeding complications.

Key words: rivaroxaban, cholecystectomy, treatment

Folia Cardiologica 2016; 11, 5: 470-472

\section{Piśmiennictwo}

1. Leandros E., Alexakis N., Archontovasilis F. i wsp. Outcome analysis of laparoscoopic cholecystectomy in patients aged 80 year older withcomplicated gallstone disease. J. Laparoendosc. Adv. Surg. Tech. A. 2007; 17: 731-736.

2. Heidbuchel H., Verhamme P., Aligns M. i wsp. European Heart Rhythm Association Practical Guide on the use of new oral anticoagulants in patients with non-valvular atrial fibrillation. Europace 2013; 15: 625-651.
3. Bhattacharya D., Senapati PS., Hurle R. i wsp. Urgent versus interval laparoscopic cholecystectomy for acute cholecystitis: a comparative study. Surg. Today. 2002; 32: 659-662.

4. De Caterina R., Husted S., Wallentin L. i wsp. New oral anticoagulants in atrial fibrillation and acute coronary syndromes: ESC Working Group on Thrombosis - Task Force on Anticoagulants in Heart Disease position paper. J. Am. Coll. Cardiol. 2012; 59: 1413-1425. 